\title{
Study of adaptation and validation of the Practice Environment Scale of the Nursing Work Index for the Portuguese reality
}

\author{
ESTUDO DE ADAPTAÇÃO E VALIDAÇÃO DA ESCALA AMBIENTE DE TRABALHO DA \\ PRÁTICA DE ENFERMAGEM PARA A REALIDADE PORTUGUESA
}

\author{
ESTUDIO DE ADAPTACIÓN Y VALIDACIÓN DE LA ESCALA DEL AMBIENTE DE \\ TRABAJO DE LA PRÁCTICA DE ENFERMERÍA PARA LA REALIDAD PORTUGUESA
}

\section{Maria Regina Sardinheiro do Céu Furtado Ferreira ${ }^{1}$, José Joaquim Penedos Amendoeira Martins²}

\begin{abstract}
Objective: Testing the psychometric properties of the Portuguese version of the Practice Environment Scale of the Nursing Work Index. Method: A descriptive, analytical and cross-sectional study, for the cross-cultural adaptation and validation of the psychometric properties of the scale. The study participants were 236 nurses from two hospitals in the regions of Lisbon and Vale do Tejo. Results: The 0.92 Cronbach's alpha was obtained for overall reliability and support of a five-dimension structure. Conclusion: The excellent quality of adjustment of analysis confirms the validity of the adapted version to hospital care settings, although there was no total coincidence of items in the five dimensions
\end{abstract}

\section{DESCRIPTORS}

Working environment

Nursing care

Nursing staff

Leadership

Validation studies

Reproducibility of results

\section{RESUMO}

Objetivo: Testar as propriedades psicométricas da versão em português da escala Practice Environment Scale of the Nursing Work Index. Método: Estudo descritivo, analítico e transversal para a adaptação transcultural e validação das propriedades psicométricas da escala. Participaram 236 enfermeiros de dois Centros Hospitalares das regiões de Lisboa e Vale do Tejo. Resultados: Obtevese um alfa de Cronbach de .92 para a confiabilidade geral e a sustentação de uma estrutura em cinco dimensões. Conclusão: A excelente qualidade de ajuste da análise corrobora a validade da versão adaptada em contextos de cuidados hospitalares, apesar da não coincidência total dos itens nas cinco dimensões.

\section{DESCRITORES}

Ambiente de trabalho

Cuidados de enfermagem

Recursos humanos de enfermagem

Liderança

Estudos de validação

Reprodutibilidade dos testes

\section{RESUMEN}

Objetivo: Validar las propiedades psicométricas de la versión en portugués de la escala Practice Environment Scale of the Nursing Work Index. Método: Estudio descriptivo, analítico, transversal de la adaptación cultural y validación de las propiedades psicométricas de la escala. Participaron 236 enfermeros de dos centros hospitalarios de la regiones de Lisboa y Vale do Tejo. Resultados: Se obtuvo un alfa de Cronbach de 0.92 para la confiabilidad general, y la sustentación de una estructura en cinco dimensiones. Conclusión: La excelente calidad del ajuste del análisis corrobora la validez de la versión adaptada a los contextos de atención hospitalarios, aunque no existe una coincidencia plena de los ítems en las cinco dimensiones.

\section{DESCRIPTORES}

Ambiente de trabajo Atención de enfermería Personal de enfermería Liderazgo

Estudios de validación

Reproducibilidad de resultados

${ }^{1} \mathrm{RN}, \mathrm{MSc}, \mathrm{PhD}$ Student at the Catholic University of Portugal, Institute of Health Sciences, Lisbon, Portugal. ${ }^{2} \mathrm{RN}, \mathrm{MSc}, \mathrm{PhD}, \mathrm{Visiting} \mathrm{Associate} \mathrm{Professor} \mathrm{at}$ the Catholic University of Portugal, Institute of Health Sciences, Lisbon, Portugal. 


\section{INTRODUCTION}

Several theoretical frameworks have been used to explain or predict the relations between the work environment, the nursing care and the outcomes. It is important to know the relationships between the characteristics of the working environment of nursing practice, the nursing care and its consequences. It is believed that the factors of the work environment can influence nursing care. It is known that the quality of care is inherent to factors of Structure, Process and Outcomes.

The effectiveness model of the nursing role ${ }^{(1)}$ emphasizes, values and characterizes the aforementioned dimensions. The Structure includes organizational factors that allow the development of work; the Process is reflected by the performance and development of activities inherent to provision of care, and the Outcomes express the effect of care, such as the level of health and satisfaction of standards and expectations. In practice, the Structure integrates the factors relative to the client, nurses and the organization. The Process integrates autonomous interventions, those resulting from medical prescriptions and interdependent such as team communication, case management and care coordination. The Outcomes consider the functional status, self-care, symptom control, side effects, customer satisfaction, among others.

The context of this study lies in aspects of the Structure. A systematic literature review of the past 12 years found that one of the most used tools to assess nursingsensitive outcomes is the Practice Environment Scale of Nursing Work Index - PESNWI. The scale was proposed based on the Nursing Work Index (NWI), and initially was composed of 49 items with the purpose of measuring the presence of organizational attributes in the work environment of nurses ${ }^{(2)}$.

In 1981, the American Academy of Nursing has developed a nationwide study to identify and assess the Magnet Hospitals, thus called by attracting and retaining nurses ${ }^{(3)}$. These hospitals had a set of organizational characteristics, namely: decentralized decision making; effective, participatory and visible management and leadership; professional recognition and autonomy, accountability, responsibility for quality of care to clients, adequate staff and flexible hours. The results showed that these features were related to job satisfaction and quality of care.

The PESNWI was constructed based on the characteristics of the Magnet Hospitals, the Nursing Work Index and the results of using this index to measure organizational attributes of hospitals ${ }^{(2)}$. It is the favorite instrument for measuring organizational characteristics of the work environment of nurses ${ }^{(4)}$ and the most widely used internationally ${ }^{(5)}$.

The concept of work environment in nursing practice is complex and defined as the characteristics of the work context that facilitate or inhibit the professional nursing practice $^{(6)}$. With the PESNWI, the authors tried to obtain appropriate measures for research models of result, which associated the environment of nursing practice with nurses and results on clients.

The guide called National Quality Forum Endorsed Nursing-Sensitive Care Performance Measures from $2009^{(7)}$, implemented by the Joint Commission, lists the PESNWI as one of the 12 measures for evaluating performance of the sensitive care in nursing. These measures are intended to analyze the factors of structure, process and outcomes of care that allow assessing the quality of care. They also start from the premise that nurses play a critical role in the care of hospitalized patients, and allow quantifying the effect that nurses and their interventions have on processes of quality of care in the evolution of the clients, being essential to support evidence-based human resource plans, understand the impact of the shortage of nurses, and optimize care outcomes. Consequently, the data collection for these measures will strengthen the available evidence and the understanding of the relationship between the structure factors, features and customer service processes, and the outcomes in the organization. Throughout time, the use of standardized specifications for these measurements will provide the basis for future comparisons between organizations and inside them.

Research has shown that the working environment factors in nursing care practice influence the evolution of the health status of clients, particularly in medical and surgical services ${ }^{(8)}$. A favorable working environment increases the interception of medication errors in intensive care $^{(9)}$. The relationship between a positive working environment and the satisfaction and retention of nurses was also demonstrated ${ }^{(10-11)}$, as well as the safety of clients ${ }^{(12-13)}$. In contrast, when the work environment is not favorable, the lack of satisfaction of nurses, the burnout syndrome, emotional exhaustion and intention to leave the place of work/service are observed ${ }^{(14-19)}$. It was demonstrated that there is a relationship between the work environment and the results observed on clients, such as mortality ${ }^{(14)}$, falls, medication errors and other adverse events ${ }^{(8)}$. There is convincing evidence that an adequate practice environment is a good predictor of quality care $\mathrm{e}^{(14,16-17,20-21)}$

The PESNWI evaluates the perception of the presence of a set of organizational characteristics in the hospital environment that support the professional nursing practice. This study aims to test the psychometric properties of the version in Portuguese.

\section{METHOD}

This is a descriptive, analytical, cross-sectional study for cross-cultural adaptation and validation of the psychometric properties of an instrument. The study participants were 236 nurses of the acute care service of two Hospi-
Study of adaptation and validation of the Practice Environment Scale of the Nursing Work Index for the Portuguese reality Ferreira MRSCF, Martins JJPA 
tals in the regions of Lisboa and Vale do Tejo: the Centro Hospitalar de Lisboa Ocidental and the Centro Hospitalar Médio Tejo.

\section{Instrument}

The PESNWI has been extensively used in different studies and contexts. It has been adapted and validated in several countries such as China, New Zealand, Spain, Australia, Switzerland, Belgium, England, Finland, Sweden, Ireland, Holland and Norway. However, a validated version for nursing care in Portugal is unknown.

The instrument consists of 31 items distributed over five subscales, including: (i) Nurse participation in hospital affairs; (ii) Nursing Foundation for Quality of Care; (iii) Management and leadership of the head/executive nurse; (iv) Adequacy of human resources for quality care; and (v) Collegial relations between nurses and physicians. The first two subscales reflect the environment around the hospital, and the remaining three refer to more specific aspects. The answers are distributed in a Likert scale of 4 points (strongly agree, agree, disagree, and strongly disagree) aimed at evaluating the perception of organizational characteristics present in nursing practice. Its psychometric properties were established by homogeneity (internal consistency and intraclass correlation) and construct validity (factor analysis). The five factors explained $48 \%$ of variance, and the coefficients of internal consistency of the subscales ranged between 0.71 and 0.84 , with a Cronbach's alpha $(\alpha)$ (total) between 0.82 and 0.94 .

\section{Procedures}

After the authors' authorization, the method of translation-back translation by two independent experts was used in the process of cultural adaptation and validation of the PESNWI for the Portuguese population. After checking the semantic equivalence of each item of the scale, there was a pre-test, in which the nurses first answered the questionnaire, and then were interviewed to evaluate whether they had understood the meaning of the questions and properly answered them.

After approval of the Board of Administration of the Hospitals of Lisboa Ocidental and Médio Tejo, and the informed consent of the key informants (nurses) for carrying out the study, came the period of data collection. The program SPSS version 19 was used for data analysis.

\section{RESULTS}

The study participants were 236 nurses, mostly females $(84.7 \%)$, aged 34 years on average ( $S D=7.52)$, ranging between 22 and 57 years. The vast majority has a licenciate's degree (91.2\%), a master's degree (5.9\%) or a bachelor's degree (2.5\%). An only nurse $(0.4 \%)$ has a PhD. The nurses work at the Centro Hospitalar Lisboa Ocidental (38.6\%) and at the Centro Hospitalar Médio Tejo (61.4\%).

Regarding the professional category, according to the Decree-Law number $437 / 91$ from $8^{\text {th }}$ November ${ }^{(22)}$, and the job position, the majority are nurses (69.3\%) and licensed nurses (25.6\%). Unit coordinators correspond to $3.8 \%$ of these professionals. Considering the totality of the sample, $87.7 \%$ work in care provision and $5.5 \%$ work as team leaders. All chiefs of service are in the category of head nurse. Among the $3.4 \%$ of specialist nurses, $2.1 \%$ work in care provision.

Regarding the work method in nursing, the majority $(98.3 \%)$ uses a method focused on the centrality of customer care (reference nurse), and only $1.7 \%$ uses the functional method.

\section{Fidelity and construct validity}

There were some steps prior to the factor analysis of items. The multicolinearity of the scale was assessed by the Bartlett's test of sphericity (BTS=3688.03; $p<0.000$ ), with extracted communalities above 0.40 . The KaiserMeyer-Olkin test $(\mathrm{KMO}=0.888)$ was used to analyze the adequacy of the factor structure of the sample, indicating that the extracted component explains a significant amount of variance of the results. Then, was performed a principal components analysis (PCA) with varimax rotation. From the analysis emerged seven components that explained $63.83 \%$ of total variance, with values of explanation of each component between $3.7 \%$ and $31.7 \%$.

Since the result obtained by the authors identified five components in the original scale, knowing that the solutions with values above one (1) tend to overestimate the number of extracted factors, and combining the result of extraction with the scree plot (another criteria to meet in the P(A), the choice was analyzing the scale forcing the extraction of five components. The results obtained by varimax rotation indicated that this solution explains $56.1 \%$ of the total variance obtained, with values of explanation of each component between $4.2 \%$ and $31.7 \%$.

With the extraction of five factors, two variables showed low communality $(0.279$ and 0.317$)$, with one of them saturating all factors with near and weak values $(0.2$ and 0.3 ), the reason for its withdrawal. By performing a new PCA (28 items) to the aforementioned procedures, the following were obtained: $\mathrm{KMO}=0.891 ; \mathrm{BTS}=3480.16$ $(p<0.000)$; extracted communalities above 0.33 . The rotation converged in six interactions (varimax).

The intraclass correlation coefficient (ICC) was also calculated, and it should exceed 0.60 to justify aggregation. Only one item of the dimension of Fundamentals of Nursing based on quality of care has value lower than 0.60 (0.54). 
Chart 1 presents the final factor solution with the distribution of items in five factors, corresponding to each dimension, and the percentage of explained variance. The total variance of this factor solution explains $59.53 \%$ and has $\alpha=0.92$.

- Factor i - Management and leadership of the head nurse. This dimension values the management and leadership of head nurses and executive nurses.

- Factor ii - Adequate human resources to ensure the quality of care. This dimension provides support for nurses in their roles of training and sharing with colleagues, developing skills and promoting autonomy.
- $\quad$ Factor iii - Nurse-physician relationship. This relationship is more commonly known as 'collegiate' because this reflects its collaborative nature and implies the autonomy of nursing and its status in the organization ${ }^{(23)}$.

- $\quad$ Factor iv - Nurse participation in hospital affairs. This dimension coincides with the original scale and values career progression as well as personal and social aspects of nurses as employees of the organization.

- $\quad$ Factor $v-$ Nursing foundation for quality of care. This dimension values the philosophy of quality of care and an expectation of a high standard service, based on a Model of Nursing in the provision of care $^{(5)}$.

Chart 1 - Structure of factor analysis with principal components extraction

\begin{tabular}{|c|c|c|c|c|c|}
\hline \multicolumn{6}{|l|}{ Factor $\mathrm{i}$ - Management and leadership of head nurse } \\
\hline Head nurse supports the nursing team $(0.57)^{*}$ & .85 & & & & \\
\hline Head nurse is a good manager and leader $(0.67)^{*}$ & .81 & & & & \\
\hline Head nurse supports the team in decision making $(0.61)^{*}$ & .81 & & & & \\
\hline Nursing supervisors use errors as learning opportunities $(0.60)^{*}$ & .69 & & & & \\
\hline Head nurse consults nurses in relation to problems and daily procedures $(0.47)$ & .64 & & & & \\
\hline Time and opportunities to discuss customer care with other nurses $(0.47)$ & .48 & & & & \\
\hline \multicolumn{6}{|l|}{ Factor ii - Adequate human resources to ensure the quality of care } \\
\hline Enough nurses ensure the quality of care $(0.71)^{*}$ & & .75 & & & \\
\hline Enough nurses carry out the work $(0.73)^{*}$ & & .74 & & & \\
\hline Active development of staff $(0.40)^{*}$ & & .63 & & & \\
\hline Nurses involved in the internal management of the hospital (0.55) & & .62 & & & \\
\hline Merit and acknowledgement of the work well done (0.55) & & .51 & & & \\
\hline Quality assurance program $(0.48)$ & & .47 & & & \\
\hline \multicolumn{6}{|l|}{ Factor iii - Nurse-physician relationship } \\
\hline Lots of work between physicians and nurses $(0.65)^{*}$ & & & .72 & & \\
\hline Group work between nurses and physicians $(0.53)^{*}$ & & & .68 & & \\
\hline Physicians and nurses have good working relationship $(0.55)^{*}$ & & & .66 & & \\
\hline Nurse director has power and authority as an executive $(0.41)$ & & & .56 & & \\
\hline Programs of embracement for newly hired nurses $(0.47)$ & & & .45 & & \\
\hline Nurse director is accessible and visible to employees $(0.48)$ & & & .49 & & \\
\hline \multicolumn{6}{|l|}{ Factor iv - Nurse participation in hospital affairs } \\
\hline Opportunity of career growth $(0.47)^{*}$ & & & & .87 & \\
\hline Opportunity of progression $(0.51)^{*}$ & & & & .83 & \\
\hline Opportunity of nurses to participate in political decisions $(0.52)^{*}$ & & & & .78 & \\
\hline Management listens and responds to the concerns of workers $(0.51)^{*}$ & & & & .57 & \\
\hline \multicolumn{6}{|l|}{ Factor $v$ - Nursing foundation for quality of care } \\
\hline Written and updated plan of care for all clients $(0.44)^{*}$ & & & & & .79 \\
\hline Use of nursing diagnosis $(0.49)^{*}$ & & & & & .76 \\
\hline Care management promotes continuity of care $(0.45)^{*}$ & & & & & .72 \\
\hline Works with competent nurses $(0.40)^{*}$ & & & & & .44 \\
\hline Nursing care are based on a nursing model $(0.45)^{*}$ & & & & & .48 \\
\hline Opportunity of nurses to participate in committees and departments $(0.42)^{*}$ & & & & & .40 \\
\hline \% Explained variance (total $=59.53)$ & 33.24 & 9.73 & 7.04 & 4.91 & 4.61 \\
\hline$\alpha($ total $=0.92)$ & .89 & .85 & .78 & .85 & .71 \\
\hline
\end{tabular}

* Items coinciding in the factor, as in the original scale (values of the original scale are in parentheses).

Study of adaptation and validation of the Practice Environment Scale of the Nursing Work Index for the Portuguese reality Ferreira MRSCF, Martins JJPA 
Chart 2 presents the analysis of internal consistency and homogeneity of the PESNWI items. Thus, the means and standard deviations are showed together with the coefficients of correlation between the item and the total scale ( $r$-itic - Corrected Item Total Correlation) and finally, the alpha coefficient for the subscale.

Chart 2 - Analysis of internal consistency and homogeneity of the scale items

\begin{tabular}{|c|c|c|c|c|}
\hline Items & Mean & SD & ritc & $\alpha *$ \\
\hline Physicians and nurses have good working relationship & 3.0 & 0.62 & 0.53 & 0.92 \\
\hline Head nurse supports the nursing team & 3.3 & 0.73 & 0.56 & 0.92 \\
\hline Active development of staff & 3.0 & 0.69 & 0.49 & 0.92 \\
\hline Opportunity of career growth & 1.7 & 0.97 & 0.46 & 0.92 \\
\hline Opportunity of nurses to participate in political decisions & 1.8 & 0.92 & 0.54 & 0.92 \\
\hline Nursing supervisors use errors as learning opportunities & 2.8 & 0.83 & 0.68 & 0.92 \\
\hline Time and opportunities to discuss customer care with other nurses & 2.7 & 0.80 & 0.70 & 0.92 \\
\hline Enough nurses ensure the quality of care & 2.2 & 0.87 & 0.61 & 0.92 \\
\hline Head nurse is a good manager and leader & 3.1 & 0.77 & 0.66 & 0.92 \\
\hline Nurse director is accessible and visible to employees & 2.5 & 0.97 & 0.59 & 0.92 \\
\hline Enough nurses carry out the work & 2.2 & 0.83 & 0.59 & 0.92 \\
\hline Merit and acknowledgement of the well done work & 2.4 & 0.84 & 0.75 & 0.91 \\
\hline Nurse director has power and authority as an executive & 2.6 & 0.82 & 0.47 & 0.92 \\
\hline Lots of work between physicians and nurses & 2.6 & 0.75 & 0.58 & 0.92 \\
\hline Opportunity of progression & 1.7 & 0.83 & 0.53 & 0.92 \\
\hline Works with competent nurses & 3.4 & 0.51 & 0.27 & 0.92 \\
\hline Head nurse supports the team in decision making & 3.0 & 0.79 & 0.53 & 0.92 \\
\hline Management listens and responds to the concerns of workers & 2.0 & 0.75 & 0.50 & 0.92 \\
\hline Quality assurance program & 2.5 & 0.74 & 0.59 & 0.92 \\
\hline Nurses involved in the internal management of the hospital & 2.0 & 0.77 & 0.55 & 0.92 \\
\hline Group work between nurses and physicians & 2.7 & 0.73 & 0.58 & 0.92 \\
\hline Programs of embracement for newly hired nurses & 2.7 & 0.82 & 0.50 & 0.92 \\
\hline Nursing care are based on a nursing model & 3.2 & 0.66 & 0.45 & 0.92 \\
\hline Opportunity of nurses to participate in committees and departments & 2.8 & 0.76 & 0.45 & 0.92 \\
\hline Head nurse consults nurses in relation to problems and daily procedures & 3.1 & 0.65 & 0.60 & 0.92 \\
\hline Written and updated plan of care for all clients & 3.4 & 0.62 & 0.28 & 0.92 \\
\hline Care management promotes continuity of care & 3.2 & 0.72 & 0.21 & 0.92 \\
\hline Use of nursing diagnosis & 3.5 & 0.57 & 0.22 & 0.92 \\
\hline
\end{tabular}

Following the analysis of fidelity and validity of the construct, was calculated an index for each of the components obtained, where 2.5 is considered neutral (1-4 range), as performed by its authors. Then, an average for each of the components per Hospital was calculated, finding the highest averages for the dimensions of management and leadership of head nurses, nurse-physician relationship, and adequacy of human resources for quality of care in the Centro Hospitalar de Lisboa Ocidental. The dimension of nursing foundation for quality of care had the highest averages in the Centro Hospitalar Médio Tejo. The dimension of participation of nurses in the affairs of the hospital had the same mean value in both contexts (Chart 3).

Chart 3 - Descriptive statistics of the subscales by hospital context

\begin{tabular}{lccccc}
\hline Subscales & N & Minimum & Maximum & Mean & SD \\
\hline Management and leadership MT & 144 & 1.00 & 4.00 & 2.89 & 0.61 \\
Management and leadership LO & 91 & 1.17 & 4.00 & 3.17 & 0.60 \\
Nurse-physician relationship MT & 145 & 1.17 & 4.00 & 2.54 & 0.56 \\
Nurse-physician relationship LO & 90 & 1.83 & 3.83 & 2.92 & 0.42 \\
Participates in hospital affairs MT & 144 & 1.00 & 4.00 & 1.80 & 0.74 \\
Participates in hospital affairs LO & 90 & 1.00 & 3.75 & 1.80 & 0.72 \\
Adequate human resources MT & 145 & 1.00 & 4.00 & 2.35 & 0.61 \\
Adequate human resources LO & 91 & 1.00 & 3.83 & 2.41 & 0.57 \\
Nursing foundation for quality MT & 145 & 2.33 & 4.00 & 3.26 & 0.41 \\
Nursing foundation for quality LO & 90 & 2.17 & 4.00 & 3.21 & 0.42 \\
\hline
\end{tabular}

Caption: MT - Centro Hospitalar Médio Tejo; LO - Centro Hospitalar Lisboa Ocidental. 


\section{Sensitivity and convergent validity}

Data indicate that, on average, nurses have a clearly positive perception of the role of head nurses as managers and leaders and they value the quality of care. However, they have a negative perception of the nursephysician relationship (Chart 4).

Chart 4 - Estatística descritiva das dimensões.

\begin{tabular}{|lcccc|}
\hline Dimensions & Minimum & Maximum & Mean & SD \\
\hline $\begin{array}{l}\text { Management and leadership of } \\
\text { head nurse }\end{array}$ & 1 & 4 & 3.00 & .62 \\
Adequate human resources & 1.17 & 4 & 2.69 & .54 \\
Nurse-physician relationship & 1 & 4 & 1.80 & .72 \\
$\begin{array}{l}\text { Nurse participation in hospital } \\
\text { affairs }\end{array}$ & 1 & 4 & 2.37 & .59 \\
$\begin{array}{l}\text { Nursing foundation for quality } \\
\text { of care }\end{array}$ & 2.17 & 4 & 3.24 & .41 \\
$\begin{array}{l}\text { Total scale } \\
\text { nat }\end{array}$ & 1.57 & 4 & 2.68 & .43 \\
\hline
\end{tabular}

Regarding the other dimensions, they are at the threshold of the neutral point, with a more positive perception of the adequacy of human resources to ensure quality of care, and a more negative perception of the nurse participation in hospital affairs (Chart 4).

Given the averages found, and the averages of dimensions per hospital setting, a t-test of two independent samples was done in order to check any statistical differences. There were significant differences between groups for the dimensions of management and leadership ( $t=-3.49 ; \mathrm{p}<0.001)$ and nurse-physician relationship $(t=-5.95 ; p<0.000)$, strengthening the foregoing in relation to differences observed in the two contexts.

Then, was analyzed the relation between the dimensions and the scale in total. It was found that in each of the dimensions the items are significantly and positively correlated with each other and with the scale. Only one item showed a significant relation at 0.05 . All others were significant at 0.01 . Correlation values ranged between 0.36 and 0.91 , with the strongest generally coinciding with the factor weights obtained by the PCA.

\section{DISCUSSION}

The results show that the dimensions obtained by factor analysis were kept despite obtaining a slightly different structure, as in other studies ${ }^{(23-24)}$. It was found that at least $50 \%$ of items in each dimension showed higher factor weights than the original scale. The items coinciding with the dimensions are presented mainly with factor weights $\geq 0.70$.
The results show that the management and leadership of the head nurse are valued, and they have been identified as a significant predictor of positive outcomes for nurses and clients ${ }^{(7,25-26)}$.

The participation of nurses is also highlighted as part of the organization to ensure quality of care, and an adequate number of nurses is required for this purpose

Team work stands out in the nurse-physician relationship, besides the good relationship between them. The role of the nurse director seems important in this dimension as an element of power and authority, as well as in programs of embracement of new nurses. An effective partnership work between nurses and doctors is an important component of a positive work environment ${ }^{(3)}$. Together with the other elements of environmental organization, this factor has been consistently identified as having significant influence on the results ${ }^{(7,14,27)}$.

The involvement of nurses in the affairs of the hospital can be an opportunity for improvement and progress in the career by sharing the concerns and participating in political decisions.

The dimension of quality of care is based on a nursing model, on the development of written and updated care plans, on continuity of care, as well as on provision of care by competent nurses. Associated with this dimension were found lower mortality rates, greater satisfaction of nurses at work, higher quality of care ${ }^{(7,28)}$ and fewer adverse events ${ }^{(29)}$.

The Cronbach alpha values found in most subscales are clearly highly satisfactory and ranged between 0.90 and 0.91 , indicating that grouped items contribute to the evaluation of the work environment factors of nursing practice.

\section{CONCLUSION}

This study aimed to test the psychometric properties of the Portuguese version of the PESNWI. For reaching this end, its translation into Portuguese was done and it was called Escala Ambiente de Trabalho da Prática de Enfermagem (Scale of Work Environment of Nursing Practice). It was applied to 236 nurses working in acute care services of the Centro Hospitalar Lisboa Ocidental and the Centro Hospitalar Médio Tejo.

The analysis of results showed the scale has internal consistency and fidelity, both as a whole $(\alpha=.92)$ as in each of the dimensions ( $\alpha$ between 0.71 and 0.89), which were subjected to factor analysis with extraction by principal components, and the model explained $59.53 \%$ of variance. In relation to dimensions, some items did not coincide with those obtained by the authors. Items with higher load were kept, and most of the weight factor values obtained were higher, as well as internal consistency values. Just as in the original instrument, strong, significant relationships were found between all the dimensions, and with the scale as a whole.
Study of adaptation and validation of the Practice Environment Scale of the Nursing Work Index for the Portuguese reality Ferreira MRSCF, Martins JJPA 
1. Irvine D, Sidani S, McGillis Hall L. Linking outcomes to nurses' roles in health care. Nurs Econ. 1998;16(2):58-64.

2. Aiken L, Patrician P. Measuring organizational traits of hospitals: the Revised Nursing Work Index. Nurs Res. 2000;49(3):146-53.

3. McClure ML, Poulin MA, Sovie MD. Magnet hospitals: attraction and retention of professional nurses. Kansas City: American Nurses Association; 1983.

4. Bonneterre V, Liaudy S, Chatellier G, et al. Reliability, validity, and health issues arising from questionnaires used to measure Psychosocial and Organizational Work Factors (POWFs) among hospital nurses: a critical review. J Nurs Meas. 2008; 16(3):207-30.

5. Warshawsky NE, Havens DS. Global use of the Practice Environment Scale of the Nursing Work Index. Nurs Res. 2011;60(1):17- 31.

6. Lake ET. Development of the Practice Environment Scale of the Nursing Work Index. Res Nurs Health. 2002;25(3):176-88.

7. The Joit Commission. Implementation Guide for the NQF Endorsed Nursing-Sensitive Care Measure Set, 2009 [Internet]. Oakbrook Terrace, Illinois ; 2009 [cited 2013 Dec 12]. Available from: http://www.jointcommission.org/assets/1/6/ NSC\%20Manual.pdf

8. Aiken LH, Clarke SP, Sloane DM, Lake ET, Cheney T. Effects of hospital care environment on patient mortality and nurse outcomes. J Nurs Adm. 2008;38(5):223-9.

9. Flynn I, Carryer J, Budge C. Organizational attributes valued by hospital home care, and district nurses in the United States and New Zealand. J Nurs Scholarsh. 2005; 37(1):67-72.

10. Cohen J, Stuenkel D, Nguyen Q. Providing a healthy work environment for nurses: the influence on retention. J Nurs Care Qual. 2009;24(4):308-15.

11. Ishihara I, IshibashI Y, Takahashi K, Nakashima M. Effect of organizational factors and work environments on newly graduated nurses' intention to leave. Japan J Nurs Scienc [Internet]. 2013 [cited 2013 Dec 20]. Available from: http:// onlinelibrary.wiley.com/doi/10.1111/jjns.12021/pdf

12. Kirwan M, Matthews A, Scott PA. The impact of the work environment of nurses on patient safety outcomes: a multi-level modelling approach. Int J Nurs Stud. 2013;50(2):253-63.

13. Smeds Alenius L, Tishelman C, Runesdotter S, Lindqvist R. Staffing and resource adequacy strongly related to RNs' assessment of patient safety: a national study of RNs working in acute-care hospitals in Sweden. BMJ Qual Saf. 2014;23(3):242-9.
14. Van Bogaert $\mathrm{P}$, Clarke $\mathrm{S}$, Roelant E, Meulemans $\mathrm{H}$, Van de Heyning P. Impacts of unit-level nurse practice environment and burnout on nurse-reported outcomes: a multilevel modelling approach. J Clin Nurs. 2010;19(11-12):1664-74.

15. Patrician PA, Shang J, Lake ET. Organizational determinants of work outcomes and quality care ratings among Army Medical Department registered nurses. Re Nurs Health. 2010;33(2):99-110.

16. Aiken LH, Sermeus W, Van den Heede K, Sloane DM, Busse $\mathrm{R}$, McKee $\mathrm{M}$, Kutney Lee A. Patient safety, satisfaction, and quality of hospital care: cross-sectional surveys of nurses and patients in 12 countries in Europe and the United States. BMJ [Internet]. 2012 [cited 2014 Apr 10];344:e1717 Available from: http://www.ncbi.nlm.nih.gov/pmc/articles/ PMC3308724/

17. Van Bogaert P, Kowalski C, Weeks SM, Van Heusden D, Clarke $S P$. The relationship between nurse practice environment, nurse work characteristics, burnout and job outcome and quality of nursing care: a cross-sectional survey. Int J Nurs Stud. 2013; 50(12):1667-77.

18. Wang S, Liu Y, Wang L. Nurse burnout: personal and environmental factors as predictors. Int J Nurs Pract. 2013; Nov 15. [Epub ahead of print]

19. Hayes B, Douglas C, Bonner A. Work environment, job satisfaction, stress and burnout among haemodialysis nurses. J Nurs Manag. 2013; Dec 30. [Epub ahead of print]

20. Choi J, Boyle DK. Differences in nursing practice environment among US acute care unit types: A descriptive study. Int J Nurs Stud. 2014 Mar 12. [Epub ahead of print]

21. Anzai E, Douglas C, Bonner A. Nursing practice environment, quality of care, and morale of hospital nurses in Japan. Nurs Health Sci. 2014;16(2):171-8.

22. Portugal. Ministério da Saúde. Decreto-Lei n.o 437, de 8 de novembro 1991. Aprova o regime legal da carreira de enfermagem. Diário da República [Internet]. 1991[citado 2013 dez. 12];Série I-A(257). Disponível em: http://www.dre.pt/ pdf1s/1991/11/257A00/57235741.pdf

23. Parker D, Tuckett A, Eley R, Hegney D. Construct validity and reliability of the Practice Environment Scale of the Nursing Work Index (PESNWI) for Queensland Nurses. J Nurs Pract. 2010;16(4):352-8.

24. Orts-Cortés MI, Moreno-Casbas T, Squires A, Fuentelsaz-Gallego , Maciá-Soler L, González-María E; consorcio RN4CASTEspaña and RN4CAST Team. Content validity of the Spanish version of the Practice Environment Scale of the Nursing Work Index. Appl Nurs Res. 2013;26(4):e5-9. 
25. Spencer Laschinger HK, Leiter MP. The impact of nursing work environments on patient safety outcomes: the mediating role of burnout/engagement. J Nurs Adm. 2006;36(5):259-67.

26. Leiter MP, Spencer Laschinger HK. Relationships of work and practice environment to professional burnout: testing a causal model. Nurs Res. 2006;55(2):137-46.

27. Gunnarsdóttir S, Clarke SP, Rafferty AM, Nutbeam D. Frontline management, staffing and nurse-doctor relationships as predictors of nurse and patient outcomes. a survey of Icelandic hospital nurses. Int J Nurs Stud. 2009;46(7):920-7.
28. Armstrong K, Laschinger $\mathrm{H}$, Wong $\mathrm{C}$. Workplace empowerment and magnet hospital characteristics as predictors of patient safety climate. J Nurs Care Qual. 2009;24(1): 55-62.

29. Tervo-Heikkinen T, Partanen $P$, Aalto $P$, Vehviläinen-Julkunen K. Nurses' work environment and nursing outcomes: a survey study among Finnish university hospital registered nurses. Int J Nurs Pract. 2008;14(5):357-65. 